2013

\title{
Aboriginal Title in Canada: Site-Specific or Territorial?
}

Kent McNeil

Osgoode Hall Law School of York University, kmcneil@osgoode.yorku.ca

Follow this and additional works at: http://digitalcommons.osgoode.yorku.ca/all_papers

\section{Repository Citation}

McNeil, Kent, "Aboriginal Title in Canada: Site-Specific or Territorial?" (2013). All Papers. Paper 19.

http://digitalcommons.osgoode.yorku.ca/all_papers/19

This Working Paper is brought to you for free and open access by the Research Papers, Working Papers, Conference Papers at Osgoode Digital

Commons. It has been accepted for inclusion in All Papers by an authorized administrator of Osgoode Digital Commons. 


\title{
Aboriginal Title in Canada: Site-Specific or Territorial?
}

\author{
Professor Kent McNeil* \\ Osgoode Hall Law School, Toronto
}

Presented at the Law on the Edge Conference, Canadian Law and Society Association/Law and Society Association of Australia and New Zealand, University of British Columbia, Vancouver, July 1-4, 2013

This paper addresses the issue of Aboriginal title to land, and the relationship I see between Indigenous law and the common law in this context. In my understanding, there have been three judicial approaches to Aboriginal title:

1. A purely proprietary approach, based on occupation of land and the effect given to occupation by the common law (common law Aboriginal title).

2. An Indigenous law approach, whereby Aboriginal title arises from and is defined by pre-existing Indigenous law (Indigenous law title).

3. A territorial approach, whereby Aboriginal title is derived from both common law and Indigenous law and has governmental dimensions (territorial Aboriginal title). ${ }^{1}$

I am going to describe each of these, and then offer some critical comments on the Supreme Court of Canada's decision in R. v. Marshall; R. v. Bernard ${ }^{2}$ and the British Columbia Court of Appeal's more recent decision in William v. British Columbia (the Tsilhqot'in Nation case). ${ }^{3}$

\section{Common Law Aboriginal Title}

It is an obvious historical fact that Indigenous peoples were living in North America, and occupying and using land in accordance with their own ways of

\footnotetext{
* In addition to the very helpful feedback received from fellow panelists and the other participants at the Law on the Edge Conference, I would like to thank Kerry Wilkins for his very useful comments.

${ }^{1}$ Brian Slattery, in "The Metamorphosis of Aboriginal Title" (2006) 85 Can. Bar Rev. 255 [Slattery, "Metamorphosis"], has identified three similar conceptions of Aboriginal title. However, he describes the third, which he supports, as "a sui generis right grounded in ancient relations between the Crown and Indigenous peoples": ibid. at 263, elaborated on at 269-79.

2 [2005] 2 S.C.R. 220 [Marshall/Bernard].

3 [2012] 3 C.N.L.R. 333 [Tsilhqot'in Nation BCCA].
} 
life, when the Europeans arrived and began to colonize the continent. In the settled parts of Canada first colonized by the British, the settlers brought the common law with them. ${ }^{4}$

Under the common law, people who are in occupation of land are presumed to have possession and thus title to the land they occupy. ${ }^{5}$ So Indigenous peoples would have title under the common law to the lands they occupied at the time of the Crown's assertion of sovereignty. ${ }^{6}$ This common law Aboriginal title neither depends on, nor is defined by, Indigenous law. It is a wholly common law concept. Moreover, it is purely proprietary - it does not necessarily entail governmental authority or political jurisdiction.

I would characterize the Supreme Court of Canada's approach to Aboriginal title in Marshall/Bernard and the British Columbia Court of Appeal's approach in the Tsilhqot'in Nation case as a proprietary, common law approach. I will come back to those decisions later.

\section{Indigenous Law Title}

In addition to occupying and using land, the Indigenous peoples of Canada had their own legal orders at the time of European colonization. ${ }^{7}$ These legal orders included laws in relation to land. ${ }^{8}$

${ }^{4}$ Connolly v. Woolrich (1867), 17 R.J.R.Q. 75 (Que. S.C.), aff'd sub nom. Johnstone v. Connolly (1969), 17 R.J.R.Q. 266 (Que. Q.B.).

${ }^{5}$ Calder v. British Columbia, [1973] S.C.R. 313 per Hall J. (dissenting on other grounds) at 368, 375 [Calder].

${ }^{6}$ Delgamuukw v. British Columbia, [1997] 3 S.C.R. 1010 at paras. 114, 149, per Lamer C.J. [Delgamuukw]; Kent McNeil, Common Law Aboriginal Title (Oxford: Clarendon Press, 1989), esp. at 196-221 [McNeil, Common Law Aboriginal Title]. Crown assertion of sovereignty also raises issues of legality and legitimacy that I have addressed elsewhere: see Kent McNeil, "Negotiated Sovereignty: Indian Treaties and the Acquisition of American and Canadian Territorial Rights in the Pacific Northwest", in Alexandra Harmon, ed., The Power of Promises: Rethinking Indian Treaties in the Pacific Northwest (Seattle: University of Washington Press, 2008), 35, and "Indigenous Nations and the Legal Relativity of European Claims to Territorial Sovereignty in North America", in Sandra Tomsons and Lorraine Mayer, eds., Philosophy and Aboriginal Rights: Critical Dialogues (Toronto: Oxford University Press, 2013), 242.

${ }^{7}$ See John Borrows, Canada's Indigenous Constitution (Toronto: University of Toronto Press, 2010).

${ }^{8}$ E.g. see Leroy Little Bear, “Aboriginal Rights and the Canadian 'Grundnorm”,, in J. Rick Ponting, ed., Arduous Journey: Canadian Indians and Decolonization (Toronto: McClelland \& Stewart, 1986), 243; Canada, Royal Commission on Aboriginal Peoples, Report of the Royal Commission on Aboriginal Peoples, vol. 2, Restructuring the Relationship (Ottawa: 
At the time of the British Crown's assertion of sovereignty, those laws and the land rights of the Indigenous peoples under those laws would have continued by virtue of the doctrine of continuity. ${ }^{9}$ This doctrine has been applied in Canada to the land rights of the French Canadians when Britain acquired New France from the French king in $1763 .^{10}$

The doctrine of continuity has also been adopted and applied in the context of the land rights of the Indigenous peoples of Australia by the High Court, initially in Mabo v. Queensland ${ }^{11}$ in 1992. As a result, in Australia the source of native title (as Aboriginal title is called there) is the pre-existing laws and customs of the Indigenous peoples. Moreover, native title in Australia also receives its content and is defined by Indigenous laws and customs. ${ }^{12}$ This sounds positive for Indigenous Australians because their laws are acknowledged and given effect. However, this approach has serious downsides. ${ }^{13}$

First of all, in order to have their land rights acknowledged by the Australian legal system, Indigenous Australians have to do more than prove that they occupied and used land at the time of Crown assertion of sovereignty. In addition, they also have to establish that they had laws or customs in relation to the land that gave them legal rights at that time. As this involves proof of the legal orders of non-literate societies over 200 years ago (in eastern Australia), the problems of proof can be formidable.

Minister of Supply and Services Canada, 1996), pt. 2, 434-64; Richard Overstall, "Encountering the Spirit in the Land: 'Property' in a Kinship-Based Legal Order", in John McLaren, A.R. Buck, and Nancy E. Wright, eds., Despotic Dominion: Property Rights in British Settler Societies (Vancouver: UBC Press, 2005), 22.

${ }^{9}$ See Brian Slattery, The Land Rights of Indigenous Canadian Peoples (Saskatoon: University of Saskatchewan Native Law Centre, 1979), 50-59; Mark D. Walters, "The 'Golden Thread' of Continuity: Aboriginal Customs at Common Law and Under the Constitution Act, 1982" (1999) 44 McGill L.J. 711; Kent McNeil and David Yarrow, "Has Constitutional Recognition of Aboriginal Rights Adversely Affected Their Definition?" (2007) 37 Supreme Court L. Rev. $\left(2^{\text {nd }}\right) 177$ at $203-11$.

${ }^{10}$ See Drulard v. Welsh (1906), 11 O.L.R. 647 (Ont. Div. Ct.), rev'd on other grounds (1907), 14 O.L.R. 54 (Ont. C.A.). Admittedly, New France is regarded as having been acquired by Britain by conquest and cession rather than by settlement, but the High Court of Australia, in the cases cited in the next two notes, has held that the doctrine of continuity applies in settled territories as well. See also McNeil, Common Law Aboriginal Title, supra note 6 at 179-92. ${ }^{11}$ (1992), 175 CLR 1.

${ }^{12}$ See Fejo v. Northern Territory (1998), 195 C.L.R. 96; Western Australia v. Ward (2002), 213 C.L.R. 1 [Ward]; Members of the Yorta Yorta Aboriginal Community v. Victoria (2002), 214 C.L.R. 422 [Yorta Yorta].

${ }^{13}$ See Simon Young, The Trouble with Tradition: Native Title and Cultural Change (Sydney: Federation Press, 2008). 
Secondly, in Australia native title rights are limited to pre-existing rights. So if at the time of Crown acquisition of sovereignty an Indigenous people did not have laws or customs in relation to minerals, for example, they are not entitled to mineral rights on their native title lands. ${ }^{14}$ The content of their land rights is thus frozen in the past at a time when they lived as hunters and gatherers.

Thirdly, under Australian law the Indigenous peoples have no inherent right of self-government. While some modification of their pre-existing land rights is possible, they have no inherent jurisdiction to make new laws in relation to land or anything else. ${ }^{15}$

Fourthly, the High Court has held that loss of connection with the land and significant gaps in the practice of Indigenous laws and customs result in loss of native title. ${ }^{16}$ This is so even if the loss of connection was caused by forcible dispossession by the colonizers. ${ }^{17}$

So far, Indigenous law has not been applied by Canadian courts in the way it has been in Australia. Justice McLachlin, as she then was, suggested in her dissent in $R$. v. Van der Peet ${ }^{18}$ that it would be appropriate to base Aboriginal rights and title at least in part on pre-existing Indigenous law, ${ }^{19}$ but her decision as Chief Justice in Marshall/Bernard is anything but an Indigenous law approach.

\section{Territorial Aboriginal Title}

Under this approach, Indigenous land rights are not limited to property rights, as they are under the first two approaches. Instead, Indigenous peoples have governmental authority (i.e., political jurisdiction) over the territories occupied by them at the time of Crown assertion of sovereignty, in addition to rights to the

\footnotetext{
${ }^{14}$ Ward, supra note 12.

${ }^{15}$ Yorta Yorta, supra note 12.

${ }^{16}$ Ibid.

${ }^{17}$ Ibid.

18 [1996] 2 S.C.R. 507 at paras. 261-75 [Van der Peet].

19 See also Mitchell v. MNR, [2001] 1 S.C.R. 911 [Mitchell], per McLachlin C.J., delivering the main judgment (Binnie and Major JJ. concurred in result), at para. 10: "aboriginal interests and customary laws were presumed to survive the assertion of sovereignty, and were absorbed into the common law as rights, unless (1) they were incompatible with the Crown's assertion of sovereignty, (2) they were surrendered voluntarily via the treaty process, or (3) the government extinguished them.... Barring one of these exceptions, the practices, customs and traditions that defined the various aboriginal societies as distinctive cultures continued as part of the law of Canada: see Calder v. Attorney-General of British Columbia, [1973] S.C.R. 313, and Mabo v. Queensland (1992), 175 C.L.R. 1 at 57 (per Brennan J.), pp. 81-82 (per Deane and Gaudron JJ.), and pp. 182-83 (per Toohey J.)."
} 
lands and resources within those territories. ${ }^{20}$ This is the approach that has been taken in the United States ever since the celebrated Cherokee Nation cases decided by Chief Justice Marshall in the 1830s. ${ }^{21}$

In numerous cases before the Indian Claims Commission that went up on review to the Court of Claims, the issue was whether the land in question had been part of the territory that the claimant Indian nation occupied and controlled for a long time before it was wrongfully taken by the United States government. ${ }^{22}$ If it had been, then prior to the taking the Indian nation would have had both title to the land and jurisdiction over it, as held by Marshall C.J. in the Cherokee cases. ${ }^{23}$

What about Canada? Although the territorial title approach was not explicitly adopted in Delgamuukw v. British Columbia ${ }^{24}$ (the leading Aboriginal title case in Canada), I think Chief Justice Lamer's decision points undeniably in that direction. He said that there are two potential sources of Aboriginal title: (1) occupation of land and the legal effect given to occupation by the common law the common law Aboriginal title approach; and (2) Aboriginal systems of law the Indigenous law approach. ${ }^{25}$

But, as I read his judgment, he then combined the two into an approach based on occupation that incorporates both physical occupation and occupation through the application of Indigenous law:

\footnotetext{
${ }^{20}$ See Kent McNeil, “Aboriginal Rights in Canada: From Title to Land to Territorial Sovereignty” (1998) 5 Tulsa J. of Comp. and Int'l L. 253, reprinted in Kent McNeil, Emerging Justice? Essays on Indigenous Rights in Canada and Australia (Saskatoon: University of Saskatchewan Native Law Centre, 2001), 58 at 95-101 [McNeil, Emerging Justice?].

${ }^{21}$ Cherokee Nation v. Georgia, 5 Pet. 1 (1831); Worcester v. Georgia, 6 Pet. 515 (1832).

${ }^{22}$ E.g. see Sac and Fox Tribe of Indians of Oklahoma v. United States, 161 Ct. Cl. 189 (1963), cert. denied 375 U.S. 921 (1963); Confederated Tribes of the Warm Springs Reservation of Oregon v. United States, 177 Ct. Cl. 184 (1966); United States v. Seminole Indians, 180 Ct. Cl. 375 (1967); Sac and Fox Tribe v. United States, 383 F. 2d 991 (1967, Ct. Cl.), cert. denied 389 U.S. 900 (1967); Turtle Mountain Band of Chippewa Indians v. United States, 490 F. 2d 935 (1974, Ct. Cl.); United States v. Pueblo of San Ildefonso, 513 F. 2d 1383 (1975, Ct. Cl.). For a very useful survey of relevant American case law, see Michael J. Kaplan, "Proof and Extinguishment of Aboriginal Title to Indian Lands" (2003) 41 A.L.R. Fed. 425. See also Cohen's Handbook of Federal Indian Law, Nell Jessup Newton, ed. (New Providence, NJ: LexisNexis, 2012), §15.04[2] [Cohen's Handbook].

${ }^{23}$ See Cohen's Handbook, supra note 22, \$15.04[2]. See also United States v. Santa Fe Pacific Railroad, 314 U.S. 339 (1941).

${ }^{24}$ Delgamuukw, supra note 6.

${ }^{25} \mathrm{Ibid}$. at para. 114.
} 
[T] he source of aboriginal title appears to be grounded both in the common law and in the aboriginal perspective on land; the latter includes, but is not limited to, their systems of law. It follows that both should be taken into account in establishing the proof of occupancy. $^{26}$

Elaborating on Indigenous law as a means of proving occupation, Lamer C.J. continued:

As a result, if, at the time of sovereignty, an aboriginal society had laws in relation to land, those laws would be relevant to establishing the occupation of lands which are the subject of a claim for aboriginal title. Relevant laws might include, but are not limited to, a land tenure system or laws governing land use. ${ }^{27}$

Other examples of relevant Indigenous laws are contained in this passage:

[T]he aboriginal group asserting the claim to aboriginal title may have trespass laws which are proof of exclusive occupation, such that the presence of trespassers does not count as evidence against exclusivity. As well, aboriginal laws under which permission may be granted to other aboriginal groups to use or reside even temporarily on land would reinforce the finding of exclusive occupation. Indeed, if that permission were the subject of treaties between the aboriginal nations in question, those treaties would also form part of the aboriginal perspective. ${ }^{28}$

Occupation through Indigenous law is a territorial approach: Indigenous peoples were in occupation of their traditional territories because they had laws, including laws in relation to land, that applied in those territories. To put it another way, they were in occupation because they exercised governmental authority over their territories, in part through the application of their own laws. Lamer C.J. acknowledged this exercise of governmental authority not only by recognizing their capacity to make their own laws, but also by concluding that permission to use lands could be granted by treaty to other Aboriginal nations, as

\footnotetext{
${ }^{26}$ Ibid. at para. 147.

27 Ibid. at para. 148.

${ }^{28}$ Ibid. at para. 157.
} 
treaty-making authority is one of the attributes of independent, self-governing nations. $^{29}$

International law relies on the same criteria for acquiring title to territory (also known as territorial sovereignty), namely, physical occupation and exercise of governmental authority. ${ }^{30}$ International law therefore recognizes that the exercise of governmental authority over land is necessarily territorial. In domestic contexts, this exercise of authority by Indigenous peoples supports continuing self-government power, whether regarded as residual sovereignty of the Indian nations, as in the United States, ${ }^{31}$ or as an inherent right of selfgovernment of First Nations, as held by Justice Williamson of the British Columbia Supreme Court in Campbell v. British Columbia. ${ }^{32}$

So by acknowledging Indigenous law as a source of Aboriginal title and as a basis for proving occupation of land, Chief Justice Lamer's approach to Aboriginal title in Delgamuukw was necessarily territorial. His conception of Aboriginal title therefore entailed both property rights and political authority. ${ }^{33}$

\section{Regressing to Common Law Aboriginal Title in Canada}

Surprisingly, in Marshall/Bernard Chief Justice McLachlin ignored the Indigenous law aspects, and hence the territorial dimensions, of Lamer C.J.'s decision in Delgamuukw. She focused instead on physical occupation, and seems to have confined the role of Aboriginal perspectives to Aboriginal

${ }^{29}$ See James Crawford, Brownlie's Principles of Public International Law, $8^{\text {th }}$ ed. (Oxford: Oxford University Press, 2012), 369-71; Malcolm N. Shaw, International Law, $6^{\text {th }}$ ed. (Cambridge: Cambridge University Press, 2008), 198, 902-4.

${ }^{30}$ Island of Palmas Case, (1928) 2 R.I.A.A. 829; Legal Status of Eastern Greenland Case, (1933) 2 P.C.I.J., Series A/B, No. 43; Minquiers and Ecrehos Case, 1953 I.C.J.R. 47. See Crawford, supra note 29 at 221-26; Shaw, supra note 29 at 502-7.

${ }^{31}$ See Cohen's Handbook, supra note 22, $\$ 4.01$.

32 [2000] 4 C.N.L.R. 1 [Campbell]. For more detailed discussion, see Kent McNeil, "Judicial Approaches to Self-Government since Calder: Searching for Doctrinal Coherence", in Hamar Foster, Heather Raven, and Jeremy Webber, eds., Let Right Be Done: Aboriginal Title, the Calder Case, and the Future of Indigenous Rights (Vancouver: UBC Press, 2007), 129 [McNeil, "Judicial Approaches"].

${ }^{33}$ See Campbell, supra note 32, esp. at paras. 134-38, where Williamson J. also relied on the fact that Lamer C.J. had held that Aboriginal title is communal and that Aboriginal nations have decision-making authority over their communally-held lands - authority that Williamson J. said must be governmental in nature. For further discussion, see Kent McNeil, "The Post-Delgamuukw Nature and Content of Aboriginal Title", in McNeil, Emerging Justice?, supra note 20 at 102 [McNeil, "Post-Delgamuukw"]; McNeil, "Judicial Approaches", supra note 32. 
practices that the common law then translates into legal rights. ${ }^{34}$ At the same time, she disagreed explicitly with the territorial approach that had been taken by Cromwell J.A. (as he then was) of the Nova Scotia Court of Appeal and Daigle J.A. of the New Brunswick Court of Appeal, favouring instead a site-specific approach whereby Aboriginal title has to be established by proof of physical occupation of specific sites (in this instance, where the Mi'kmaq accused had harvested timber).

In their minority judgment, Justices LeBel and Fish disagreed forcibly with McLachlin C.J.'s approach, which they thought relied too heavily on the common law and did not take account of Indigenous law and Indigenous conceptions of territory. ${ }^{35}$

I find McLachlin C.J.'s decision puzzling, in part because she concurred with Lamer C.J. in Delgamuukw and thus seemed to endorse his acceptance of the role of Indigenous law in proving occupation, which I have argued is necessarily a territorial approach. ${ }^{36}$ She also purported to follow the Delgamuukw decision in Marshall/Bernard. Moreover, in previous judgments she spoke of the "golden thread" of continuity of Indigenous law from pre-contact times to the present and said that Aboriginal rights that are sourced in Indigenous law continue until either surrendered by treaty or extinguished by legislation. ${ }^{37}$

Unfortunately, Chief Justice McLachlin's limited, common law approach and her reliance on physical occupation have now been applied even more strictly by the British Columbia Court of Appeal in the Tsilhqot'in Nation case. Moreover, Justice Groberman, whose judgment was concurred in by Levine and Tysoe JJ.A., adopted the site-specific approach used by McLachlin C.J. in Marshall/Bernard, even though Justice Vickers at trial in Tsilhqot'in Nation had pointed out that an Aboriginal title claim to a territory is different from a claim to Aboriginal title to specific sites in the context of a defence to a prosecution, as in Marshall/Bernard. ${ }^{38}$

34 For critical commentary, see "Special Forum: Perspectives on R. v. Marshall; R. $v$. Bernard" (2006) 55 U.N.B.L.J. 73; Slattery, supra note 1 at 279-81.

${ }^{35}$ Marshall/Bernard, supra note 2, esp. at paras. 110, 127-30. LeBel and Fish JJ. concurred in result on the basis of the evidence, but disagreed with the majority on the correct approach to proving Aboriginal title.

${ }^{36}$ For critical discussion, see Kent McNeil, "Aboriginal Title and the Supreme Court: What's Happening?” (1996) 69 Sask. L. Rev. 281 [McNeil, "What's Happening?’].

${ }^{37}$ Van der Peet, supra note 18 at paras. 263-67; Mitchell at para. 10, quoted in note 19 supra.

${ }^{38}$ See Tsilhqot'in Nation v. British Columbia, [2008] 1 C.N.L.R. 112 at para. 582 [Tsilhqot'in Nation BCSC]. On the inappropriateness of litigating Aboriginal title claims in the context of 
Justice Groberman limited Aboriginal title to "definite tract[s] of land the boundaries of which are reasonably capable of definition." $39 \mathrm{He}$ regarded definite tracts as "specific sites on which hunting, fishing, or resource extraction activities took place on a regular and intensive basis", such as "salt licks, narrow defiles between mountains and cliffs, particular rocks or promontories used for netting salmon, or, in other areas of the country, buffalo jumps". ${ }^{40}$ However, in the numbered treaties, where vast areas of land were surrendered, the whole treaty area was defined and referred to as a "tract", revealing that the term "definite tract" tells us nothing about the size of the area in question. ${ }^{41}$ Moreover, when Lamer C.J. stated in Delgamuukw that physical occupation could be established by "regular use of definite tracts of land for hunting, fishing or otherwise exploiting its resources", ${ }^{42}$ he did not say that the use had to be intensive - that qualification was added by Justice Groberman. ${ }^{43}$ Instead, Lamer C.J. referred to the following passage from my book, Common Law Aboriginal Title:

Definite tracts over which they [the Indigenous people in question] herded domestic animals, and lands to which they resorted on a regular basis to hunt, fish, or collect the natural products of the earth, should be included [in the area occupied by them] as well, particularly if other individuals and groups were generally excluded therefrom. Probably even outlying areas that were visited occasionally, and regarded as being under their exclusive control, would also be occupied by them in

prosecutions, see Marshall/Bernard, supra note 2 at paras. 142-44, per LeBel J.; Shin Imai, "The Adjudication of Historical Evidence: A Comment and an Elaboration on a Proposal by Justice LeBel” (2006) 55 U.N.B.L.J. 146.

${ }^{39}$ Tsilhqot'in Nation BCCA, supra note 3 at para. 230.

${ }^{40}$ Ibid. at para. 221.

${ }^{41}$ E.g. see Treaty 3 (1873), in Alexander Morris, The Treaties of Canada with the Indians (Toronto: Belfords, Clarke \& Co., 1880), 320 at 322: "The tract comprised within the lines above described embracing an area of fifty-five thousand square miles". Treaty 8 (1899), covering an even larger area, provided that "the said Indians ... shall have right to pursue their usual vocations of hunting, trapping and fishing throughout the tract surrendered as hereinbefore described": Treaty No. 8, reprinted from the 1899 edition (Ottawa: Queen's Printer, 1966), 12.

42 Delgamuukw, supra note 6 at para. 149.

${ }^{43}$ McLachlin C.J. did use the word "intensive" in Marshall/Bernard, supra note 2, but not as a requirement. She stated at para. 70: "In summary, exclusive possession in the sense of intention and capacity to control is required to establish aboriginal title. Typically, this is established by showing regular occupancy or use of definite tracts of land for hunting, fishing or exploiting resources: Delgamuukw, at para. 149. Less intensive uses may give rise to different rights." 
much the same way as the waste of a manor would be occupied by the lord, though he might seldom go there. ${ }^{44}$

As we shall see below, the common law standard for occupation that Lamer C.J. found to be applicable in this context does not require intensive use, or indeed any use at all in some circumstances - rather, what really counts is the intention to possess and the exclusion of others.

My main criticisms of the British Columbia Court of Appeal decision in the Tsilhqot'in Nation case are therefore twofold. ${ }^{45}$ First, even if one accepts (which I do not $^{46}$ ) that Aboriginal title depends exclusively on physical occupation of definite tracts of land, the test for occupation applied by the British Columbia Court of Appeal is inconsistent with common law authority relating to occupation of land and is therefore too strict. ${ }^{47}$ My second criticism is that the site-specific, non-territorial approach is simply wrong. It pays too much attention to physical occupation and disregards Indigenous law. As discussed above, this approach is inconsistent with the Delgamuukw decision.

\section{The Common Law Standard for Occupation}

I examined the common law requirements for occupation of land and related them to proof of Aboriginal title in Common Law Aboriginal Title, ${ }^{48}$ and so will only summarize the main points here. The case law reveals that occupation of land is a question of fact that depends on all the circumstances. The nature of the land and the uses to which it could reasonably be put at the relevant time have to be taken into account. Lord O'Hagan put it this way in Lord Advocate v. Lord Lovat:

${ }^{44}$ McNeil, Common Law Aboriginal Title, supra note 6 at 202 (footnote omitted).

${ }^{45}$ For further criticism of the decision by a retired judge of the British Columbia Court of Appeal, see Douglas Lambert, “The Tsilhqot'in Case" (2012) 70:6 The Advocate 819.

${ }^{46}$ In Common Law Aboriginal Title, supra note 6, I presented Indigenous law title (ch. 6) and common law title (ch. 7) as alternative approaches. In Delgamuukw, Lamer C.J. combined these two approaches to produce the territorial approach described above. Thereafter, I modified my own views to take into account the jurisdictional aspects of Aboriginal title: see McNeil, "Post-Delgamuukw", supra note 33; Kent McNeil, "Self-Government and the Inalienability of Aboriginal Title" (2002) 47 McGill L.J. 473; McNeil, "What's Happening?", supra note 36. See also Slattery, supra note 1.

${ }^{47}$ See also Nicole Petersen, "The Standard of Occupation for Aboriginal Title in William v. British Columbia", April 2013, unpublished research paper.

${ }^{48}$ Supra note 6 at 196-204. 
The character and value of the property, the suitable and natural mode of using it, the course of conduct which the proprietor might reasonably be expected to follow with a due regard to his own interests - all these things, greatly varying as they must, under various conditions, are to be taken into account in determining the sufficiency of a possession. ${ }^{49}$

A large variety of acts can therefore demonstrate occupation, including perambulation, ${ }^{50}$ hunting, ${ }^{51}$ fishing, ${ }^{52}$ cutting grass, ${ }^{53}$ and even blazing trees. ${ }^{54}$ In one case that went up on appeal from the British Columbia Court of Appeal to the Privy Council in London, mere payment of taxes on wild, unimproved land was held to be sufficient evidence of occupation to confer title. ${ }^{55}$ In another case where the only act of occupation was placing markers at the four corners of the land, the Privy Council found that to be sufficient. Lord Guest observed:

Their Lordships do not consider that in order to establish possession it is necessary for a claimant to take some active step in relation to the land such as enclosing the land or cultivating it. The type of conduct which indicates possession must vary with the type of land. In the case of vacant and unenclosed land which is not being cultivated there is little which can be done on the land to indicate possession. ${ }^{56}$

Moreover, in assessing the acts of occupation, "the conditions of life and habits and ideas of the people" living there should be taken into account. ${ }^{57}$ The relevant considerations are therefore social and cultural as well as physical.

49 (1880), 5 App. Cas. 273 at 288 (H.L.), approved in Johnston v. O'Neill, [1911] A.C. 552 at 583 (H.L.). See also the list of cases cited in McNeil, Common Law Aboriginal Title, supra note 6 at 200 n. 27 . Note that, while many of the authorities I am relying on are from the $19^{\text {th }}$ and early $20^{\text {th }}$ centuries, this is appropriate because the time when the Tsilhqot'in have to prove their occupation is 1846, the date at which Vickers J. held that the Crown had asserted sovereignty over their territory: Tsilhqot'in Nation BCSC, supra note 38 at paras. 601-2.

${ }^{50}$ Woolway v. Rowe (1834), 1 Ad. \& E. 114 (K.B.).

${ }^{51}$ Red House Farms Ltd. v. Catchpole (1976), 244 E.G. 295 (Engl. C.A.) [Red House Farms].

${ }^{52}$ Curzon v. Lomax (1803), 5 Esp. 60 (K.B.); Bristow v. Cormican (1874), Ir. R. 10 C.L. 398 at 408 (Ex.), aff'd (1878), 3 App. Cas. 641 (H.L.).

${ }^{53}$ Cadija Umma v. S. Don Manis Appu, [1939] A.C. 136 (P.C.) [Cadija Umma].

${ }^{54}$ Halifax Power Co. v. Christie (1915), 48 N.S.R. 264 at 267 (N.S.S.C.) [Halifax Power].

${ }^{55}$ Kirby v. Cowderoy, [1912] A.C. 599 at 602-3 [Kirby].

${ }^{56}$ Wuta-Ofei v. Danquah, [1961] 1 W.L.R. 1238 at 1243 (P.C.) [Wuta-Ofei] (emphasis added).

${ }^{57}$ Cadija Umma (on appeal from Ceylon), supra note 53 at 141-42, per Sir George Rankin. 
At least as important as physical acts on or in relation to the land is the intention to hold and use the land for one's own purposes and to exclude others who have not been given permission to enter. ${ }^{58}$ This is why placing markers or blazing trees around the perimeter of the land demonstrate occupation, even if the land is not otherwise occupied or used. ${ }^{59}$ In other words, the occupier is not obliged to use the land in any particular way, as long as the intention to occupy is present and manifest through public acts in relation to the land and no one else is in actual occupation. ${ }^{60}$

In Marshall/Bernard, McLachlin C.J. held that, in assessing occupation in order to determine whether Aboriginal title has been proven, a court has to decide whether the Aboriginal relationship with the land was such that it could be translated into title at common law. ${ }^{61}$ Relying on English case law, ${ }^{62}$ she affirmed that " $[\mathrm{t}]$ he common law recognizes that possession sufficient to ground title is a matter of fact, depending on all the circumstances, in particular the nature of the land and the manner in which the land is commonly enjoyed". ${ }^{63}$ She noted as well that, "where marshy land is virtually useless except for shooting, shooting over it may amount to adverse possession", and "that a person with adequate possession for title may use it intermittently or sporadically". ${ }^{64}$ Citing Delgamuukw, she also said that "the common law recognizes that exclusivity does not preclude consensual arrangements that recognize shared title to the same parcel of land". 65

Chief Justice McLachlin emphasized that assessment of the practices relied upon to establish title must take into account the Aboriginal perspective:

The aboriginal perspective grounds the analysis and imbues its every step. It must be considered in evaluating the practice at issue, and a

${ }^{58}$ See Frederick Pollock and Robert Samuel Wright, An Essay on Possession in the Common Law (Oxford: Clarendon Press, 1888), 28-36; John M. Lightwood, A Treatise on Possession of Land (London: Stevens and Sons Ltd., 1894), 9-27; R.D.C. Stewart, "The Differences between Possession of Land and Chattels" (1933) 11 Can. Bar Rev. 651 at 652-56.

${ }^{59}$ Wuta-Ofei, supra note 56; Halifax Power, supra note 54.

${ }^{60}$ This explains why payment of taxes on the land was sufficient to establish occupation in Kirby, supra note 55.

${ }^{61}$ Marshall/Bernard, supra note 2 at paras. 48-51, 69-70, 78.

${ }^{62}$ Powell v. McFarlane (1977), 38 P. \& C.R. 452 at 471 (Ch.D.).

${ }^{63}$ Supra note 2 at para. 54.

${ }^{64}$ Ibid., citing Red House Farms, supra note 51, and Keefer v. Arillotta (1976), 13 O.R. (2d) 680 (C.A.), per Wilson J.A.

${ }^{65}$ Marshall/Bernard, supra note 2 at para. 54, citing Delgamuukw, supra note 6 at para. 158. 
generous approach must be taken in matching it to the appropriate modern right. ${ }^{66}$

For example, she commented as follows on the requirement of exclusivity:

[T]he people may have been peaceful and have chosen to exercise their control by sharing rather than exclusion. It is therefore critical to view the question of exclusion from the aboriginal perspective.... It follows that evidence of acts of exclusion is not required to establish aboriginal title. All that is required is demonstration of effective control of the land by the group, from which a reasonable inference can be drawn that it could have excluded others had it chosen to do so. ${ }^{67}$

At common law, effective control can be demonstrated by regular use of the land, but does not depend on use of specific sites. Indeed, the common law cases clearly reveal that control of, or even notice of intention to control, the perimeter of a tract of land is sufficient to establish occupation of all the land within the perimeter. ${ }^{68}$

Most of the common law cases in which the issue of sufficiency of occupation has arisen have involved adverse possession where a wrongdoer claimed to have acquired a possessory title by ousting the rightful owner for the statutory limitation period. Aboriginal peoples claiming Aboriginal title are obviously not wrongdoers - on the contrary, they are claiming title because they were in rightful occupation of their traditional lands at the time of Crown assertion of sovereignty. The standard to be applied in determining whether they had the occupation required for title should therefore be considerably lower than that required for persons claiming title by adverse possession. ${ }^{69}$

However, in Tsilhqot'in Nation it is apparent that the British Columbia Court of Appeal applied a standard higher even than the standard for adverse possession

${ }^{66}$ Marshall/Bernard, supra note 2 at para. 50. See also paras. 45-49, 51, 64, 69-70, 78.

${ }^{67} \mathrm{Ibid}$. at paras. 64-65.

${ }^{68}$ Wuta-Ofei, supra note 56; Halifax Power, supra note 54.

${ }^{69}$ See $R$. v. Marshall, [2004] 1 C.N.L.R. 211, per Cromwell J.A. (as he then was) at paras. 124-38; McNeil, Common Law Aboriginal Title, supra note 6 at 197-99. Even in adverse possession cases, judges have been much more willing to accord possession to "innocent" persons (i.e. those who honestly and mistakenly occupy someone else's land) than to conscious wrongdoers: see Wood v. Gateway of Uxbridge Properties Ltd. (1990), 75 O.R. (2d) 769 (Ont. Gen. Div.); Teis v. Ancaster (Town) (1997), 152 D.L.R. ( $\left.4^{\text {th }}\right) 304$ (Ont. C.A.); Elliott v. Woodstock Agricultural Society (2008), 298 D.L.R. $\left(4^{\text {th }}\right) 577$ at para. 29 (Ont. C.A.). 
by wrongdoers. Without referring to a single case involving sufficiency of occupation at common law, Groberman J.A. concluded that intensive and regular use of definite tracts of land is necessary to establish the occupation required for Aboriginal title. With all due respect, his test is inconsistent with the common law standard, approved by McLachlin C.J. in Marshall/Bernard, which we have seen is more concerned with intention to control and exclusion of others than with specific use of the land, or indeed any use at all. ${ }^{70}$

Also missing from Groberman J.A.'s analysis is any serious assessment of the Aboriginal perspective, which McLachlin C.J. said "grounds the analysis and imbues its every step." J11 Judges should therefore be examining the evidence carefully to determine what uses and what standard of occupation and exclusion are appropriate to the specific Aboriginal society at the time in the geographical location in question, taking into account, as Lamer C.J. directed in Delgamuukw and McLachlin C.J. affirmed in Marshall/Bernard, "the group's size, manner of life, material resources, and technological abilities, and the character of the lands claimed". ${ }^{72}$ This approach is also in keeping with the common law, which directs that "the conditions of life and habits and ideas of the people" need to be taken into account. ${ }^{73}$

\section{Conclusion: Applying Delgamuukw}

In summary, the main problems I have identified with a strictly common law approach to Aboriginal title are that it ignores Indigenous law and does not include governmental authority. As a consequence, it does not take into account the significant developments in the jurisprudence in the Delgamuukw and Campbell decisions. Moreover, the British Columbia Court of Appeal decision in Tsilhqot'in Nation, while purporting to take a common law approach, in fact applied a test for Aboriginal occupation that is much stricter even than the common law test for adverse possessors who are known wrongdoers. The

${ }^{70}$ See especially Kirby, supra note 55, a Privy Council decision on appeal from the British Columbia Court of Appeal, and Wuta-Ofei, supra note 56. See also the quotation from McLachlin C.J.'s judgment in Marshall/Bernard, supra note 43.

${ }^{71}$ Marshall/Bernard, supra 2 at para. 55: see text accompanying note 66 supra.

${ }^{72}$ Delgamuukw, supra note 6 at para. 149, quoting from Brian Slattery, "Understanding Aboriginal Rights" (1987) 64 Can. Bar Rev. 727 at 758, adopted in Marshall/Bernard, supra note 2 at para. 49. McLachlin C.J. also approved La Forest J.'s statement in Delgamuukw that, "when dealing with a claim of 'aboriginal title', the court will focus on the occupation and use of the land as part of the aboriginal society's traditional way of life": Delgamuukw, supra note 6 at para. 194 (emphasis in original), quoted in Marshall/Bernard, supra note 2 at para. 49.

${ }^{73}$ Cadija Umma, supra note 53 at 141-42, per Sir George Rankin. 
standard of occupation applied by the Court of Appeal is therefore discriminatory and must be rejected.

The Indigenous law approach, while acknowledging the existence and continuing application of Indigenous law, suffers from serious shortcomings that have become glaringly apparent in Australia: (1) in addition to showing a connection with the land, Indigenous peoples in Australia have to prove they had laws or customs that gave them rights in relation thereto prior to Crown acquisition of sovereignty; (2) the content of their land rights is limited to the rights under their pre-existing laws and customs; (3) they have no inherent governmental authority that would permit them to make new laws or significantly change their pre-existing laws; and (4) loss of their connection with the land and discontinuance of their laws and customs in relation thereto result in loss of their land rights.

In Delgamuukw, Chief Justice Lamer adopted the common law approach, but went significantly beyond it by incorporating Indigenous law into the test for establishing Aboriginal title. In so doing, he acknowledged the importance and relevance of Indigenous law, while avoiding the problems with native title in Australia by not relying on Indigenous law to define the content of Aboriginal title. Instead, he maintained that Indigenous law is a source of Aboriginal title that can be used to prove the occupation upon which the title depends. Given that a society's laws in relation to land are generally territorial in their application, ${ }^{74}$ Lamer C.J.'s conception of Aboriginal title is necessarily territorial. Moreover, as held by Justice Williamson in the Campbell decision, Aboriginal title as conceptualized by Lamer C.J. includes governmental authority. Unlike Aboriginal title under a strictly common law approach, it is more than a proprietary interest. It is also jurisdictional.

Chief Justice Lamer's approach to Aboriginal title is an innovative advance in the jurisprudence that was concurred in by the current Chief Justice. It resolves the dilemma of having to choose between the common law and Indigenous law as the source of Aboriginal title. At the same time, it can be used to explain the distinction between the external and internal aspects of Indigenous title, identified by Brian Slattery. ${ }^{75}$ Externally, as against the outside world, Aboriginal title is a generic right that, subject to the limit that the lands cannot be

\footnotetext{
${ }^{74}$ The kinds of laws Lamer C.J. gave as examples - trespass laws, a land tenure system, and laws governing land use - tend to be laws of general application that typically would apply throughout an Indigenous people's territory. See quotations accompanying notes 27 and 28, supra.

${ }^{75}$ Slattery, "Metamorphosis", supra note 1 at 270, 279.
} 
used in ways irreconcilable with the connection with the land on which the title is based, ${ }^{76}$ does not vary from one title-holding group to another. Internally, the Indigenous law of each group continues to apply to govern landholding within their territory. Moreover, this law is not frozen in time at the moment of Crown assertion of sovereignty. It is dynamic, and can be modified at any time through the exercise of the group's right of internal self-government. ${ }^{77}$

We have seen that the British Columbia Court of Appeal's decision in the Tsilhqot'in Nation case deviated substantially from both the common law standard for occupation of land and the Delgamuukw decision on the role Indigenous law in proving Aboriginal title. In January, 2013, the Supreme Court of Canada granted leave to appeal. The appeal is scheduled to be heard on November 7 of this year. With all due respect, I think the Supreme Court should overturn Justice Groberman's decision and apply the combined common law/Indigenous law approach to proof of Aboriginal title that was firmly established by the Court's own decision in Delgamuukw.

${ }^{76}$ Delgamuukw, supra note 6 at paras. 125-32. For criticism of this inherent limit on Aboriginal title, see McNeil, "Post-Delgamuukw", supra note 33 at 116-22.

${ }^{77}$ Campbell, supra note 32. See also Brian Slattery, "Making Sense of Aboriginal and Treaty Rights" (2000) 79 Can. Bar Rev. 196 at 212-15; McNeil, "What's Happening?", supra note 36 at 291-93. 